\title{
TRENDS IN TRANSPORTATION EMPLOYEE INJURIES SINCE ECONOMIC DEREGULATION
}

\author{
Ian Savage \\ Department of Economics and the Transportation Center \\ Northwestern University
}

$\underline{\text { Mailing Address }}$

Department of Economics

Northwestern University

2001 Sheridan Road

Evanston, IL 60208

Ph: (847) 491-8241

Fax: (847) 491-7001

E-mail: ipsavage@northwestern.edu

Published in James Peoples and Wayne Talley (editors) Research in Transportation Economics: Transportation Labor Issues and Regulatory Reform. Volume 10, pages 11-33. Elsevier Science, 2004. 


\begin{abstract}
This paper investigates whether economic deregulation affected the rate of workplace injuries in the railroad, trucking and commercial aviation industries. Bureau of Labor Statistics data for the period 1973-2001 are used to compare these three industries with the trend for comparable occupations in manufacturing. The railroad industry witnessed declining workplace safety in the years prior to deregulation. The subsequent financial renaissance of the industry led to a very notable improvement. In contrast, employee injury rates in trucking and aviation have remained very stable over the past thirty years, and there is no evidence of any effects associated with deregulation.
\end{abstract}


Most of the research on the linkage between economic deregulation and transportation safety has analyzed changes in the rate of crashes. While employees are killed and injured in these crashes, the vast majority of employee injuries occur in less spectacular circumstances. Government data for the year 2000, shown in Table 1, suggests that less than one in nine employee injuries and illnesses in railroads and trucking, and one in twenty-five in commercial aviation, are due to a crash. Federal Railroad Administration data suggests that $85 \%$ of railroad employee injuries do not even involve a moving train. Many injuries occur during maintenance activities. At least a fifth results from slips and falls. In aviation, two fifths of workplace injuries and illnesses are due to overexertion, which includes injuries sustained while lifting objects. Consistent with the leading causal events, the majority of the injuries and illnesses sustained by employees are sprains, strains, cuts and bruises. As shown in Table 2, burns, amputations and trauma represent a very small minority of injuries. Consequently one has to look beyond crash data to determine the effects of deregulation on the safety of employees.

The only previous research that used employee injury data was conducted shortly after deregulation. Viscusi $(1987,1989)$ analyzed trends for railroads (reported in the 1987 paper only), aviation and trucking using data from 1972 (when the data were first collected) through 1985. Consequently, he had only a limited amount of data to work with. As deregulation occurred in 1978 for the airlines and 1980 for railroads and trucking, there was very limited before and after data, and it was not surprising that he did not find any statistically significant relationships.

The availability of fifteen years more data permit more reflection on the events since deregulation. Some of the effects of deregulation may not have been apparent when Viscusi conducted his analysis in the mid-1980s. Airline deregulation was phased in over the period from 1978 to 1983, the economic downturn of the early 1980s limited the post-deregulation expansion of all three industries, and the trucking industry at the local "intrastate" level was not fully deregulated until 1995. Yet a time series analysis is still problematic because the pre-deregulation data is limited. In addition, factors unrelated to deregulation, such as changes in technology, attitudes, and public policy, may have altered workplace safety in the past quarter century. Therefore, unlike Viscusi, this paper compares the experiences of the transportation industries with a control group of comparable occupations in manufacturing.

\section{Why Deregulation Might Effect Workplace Safety}

Why might one expect that deregulation would change workplace safety? Economic models explain that a firm's choice of workplace safety is not made in isolation. A profit-maximizing firm has to simultaneously choose product price, the wage rate offered, workplace and product safety, and other quality attributes of its product. Market changes that affect one of these variables will usually have a knock-on effect on all of the other variables. Deregulation was expected to have a major influence on the price and quality of transportation services. Consequently, it would not be surprising if workplace safety was also affected. This would be particularly the case if there is a correlation between the level of safety enjoyed by a firm's employees and the safety of the service which is sold to its customers.

For example, if regulation had limited the supply of low-quality services, then there would be a proliferation of such services after deregulation and a consequent decline in average 
workplace safety. There was a school of thought that the airlines had over provided quality during the period of regulation when they were constrained from competing on price. Instead, they competed by providing high service frequencies, new equipment, and in-flight frills. After deregulation, average load factors increased and in-flight amenities declined. It would not have been surprising if this decline in quality, either implicitly or explicitly, extended to safety.

Regulation of the trucking industry was marked by restrictions on entry. Moreover, a large proportion of trucking firms had unionized labor. The labor economics literature recognizes that unionization tends to increase workplace safety. Unions represent the infra-marginal worker rather than the tastes of the marginal worker who determines safety in a competitive marketplace. Infra-marginal workers tend to be older and have a lower tolerance for risk. To the extent that customers desiring lower-quality service were not well provided for under regulation, one might expect trucking deregulation to lead to the entry of lower-safety firms, and a consequent diminishing of average workplace safety.

Safety, unlike price, is difficult for consumers to observe. Customers have to form opinions regarding the safety performance of the firms that they use. Firms build up a reputation for providing a certain quality of service. In all three industries, regulation limited entry and ensured the continuance of existing firms. These firms had ongoing relationships with their customers and had incentives to consider the effect on their reputation if they shaded on safety. The same is not true in a deregulated environment. Industrial organization economists describe how it is profitable for some firms to "cheat" by posing as high-quality firms and charging a premium price, whereas in reality they are low-quality firms (Klein and Leffler, 1981; Shapiro, 1982). By the time the consumers become aware of the deception, the firms have earned a profit, and can exit the industry before there is a consumer backlash. These types of firms do not worry about their long term reputation. The emergence of such "fly-by-night" firms was feared in both the trucking and airline industries.

Deregulation lowers the barriers to entry, and in all three industries it was feared that some of the new entrants would offer lower levels of safety than the market desires. Some firms would be motivated by avarice, as described in the previous paragraph, but others would suffer from pure inexperience. Safety has the characteristic that the costs, in the form of equipment and training, are incurred up front, yet the "benefits" in the form of a reduced number of crashes occur in a probabilistic fashion over the course of many years. Many new entrants may be very aware of the costs of providing safety, yet are genuinely unaware of the financial implications of crashes. To the extent that their customers cannot observe, at least in the short run, the true level of safety on offer, these firms may provide unjustifiably low safety in their initial period of operation.

Deregulation was expected to shake up the existing market structure, and remove poorly-managed firms. There is a theoretical literature that indicates that firms close to bankruptcy may also be motivated to cheat their customers by reducing safety (Bulow and Shoven, 1978). These firms can reduce expenses by cutting maintenance and training, yet can declare bankruptcy to protect against claims in the event that a major crash occurs.

All in all, every indication was that deregulation would be expected to reduce safety, especially in trucking and aviation. The symptoms were expected to be entry of firms who 
deliberately and openly provide low safety service, "fly-by-night" cheaters, inexperienced new entrants, and financial distress among some existing firms who are unable to adapt to the new market realities.

\section{Empirical Literature on Deregulation and Safety}

In the mid-1980s there was a fear that the gloomy predictions were coming true. Aviation had one of its worse years for safety in 1985, and Congress had introduced considerable legislation aimed at perceived safety problems in the trucking industry. The concern led to an academic conference in 1987 that looked at many different aspects of safety after deregulation in the aviation and trucking industries (Moses and Savage, 1989). Data on the frequency of crashes was brought up to date in Savage (1999a), who also analyzed the safety performance of the railroad industry. To the extent that crashes do injure employees, and might be symptomatic of workplace safety in general, it is worthwhile to briefly describe the experience in each of the industries.

In the railroad industry, the rate of collisions and derailments started to increase in the 1960s, reversing decades of improvement. In part this was caused by the bankruptcy, or near bankruptcy, of much of the railroad system in the eastern United States which led to disinvestment in the capital stock. Comprehensive safety regulation was introduced with the Federal Railroad Safety Act of 1970 which predated deregulation by ten years. While many new regulations were developed in the early 1970s, it was only later in the decade that the government deployed an inspectorate to enforce the regulations. This coincided with economic regulatory reform. In 1976 the Railroad Revitalization and Regulatory Reform (“4R”) Act exempted some commodities from price regulation and started a process by which railroads could abandon unprofitable branch lines. The Staggers Act of 1980 gave railroads greater freedom to negotiate prices with shippers of all commodities and to spin-off poorly-used secondary lines. The financial health of the industry improved considerably, especially after the Staggers Act. The railroads were able to increase maintenance expenditures and rebuild their capital stock. At the same time, more traffic was moving in "unit trains" which do not require switching. This is a safer form of operation as a disproportionate number of collisions and derailments occur during switching operations. The combination of a financial renaissance following deregulation, government safety regulations, and reduced switching led to a dramatic reversal of the upward trend in collisions and derailments. Between 1978 and the mid-1990s, the rate of collisions and derailments fell by 75\%. Because these three explanatory factors are highly collinear, there has been considerable disagreement as to their relative contribution to the improvement (Savage, 1998).

The trucking industry has also seen a substantial improvement in safety in the years since the Motor Carrier Act of 1980. The number of fatal crashes involving large trucks, those with a gross vehicle weight greater than 10,000 lbs., has declined somewhat, while truck miles have more than doubled. (Data on crashes that involve only injury or property damage are less reliable, and it is difficult to draw conclusive inferences.) Much of the improvement has occurred because the roads in general are safer. Improved automotive technology, better occupant protection, better emergency medical response and changing attitudes to the use of seat belts and drunk-driving have contributed to safer highways. There is evidence that the fatal crash rate for large trucks has declined at a faster rate than the average for all vehicles on the road. 
This outcome was not expected at the time of deregulation, when there was a great fear that safety would diminish. There was considerable new entry, especially involving small firms with poorer than average safety records (Corsi and Fanara, 1989). Many middle-sized firms suffered from severe price competition and had to exit the market. The government responded by introducing explicit safety regulations and enhanced enforcement in the Surface Transportation Assistance Act of 1982, the Motor Carrier Safety Act of 1984 and the Commercial Motor Vehicle Safety Act of 1986. These Acts tightened vehicle standards, and introduced a coordinated national Commercial Drivers License. The new license requirements imposed uniform testing across states, and prevented drivers from holding multiple licenses as a way of avoiding the consequences of revocation in one jurisdiction. Many states had to raise driver-testing standards considerably. In addition, federal funding allowed increased enforcement through safety audits of carriers and semi-random inspections at the roadside (Moses and Savage, 1997). Enforcement was further enhanced by the Motor Carrier Safety Improvement Act of 1999 which increased funding and established a separate administration for motor carrier safety within the federal Department of Transportation.

There is evidence that the rate of improvement in safety for mainline ("Part 121") airlines in the 1960s and 1970s did not continue after the Airline Deregulation Act of 1978 (Savage, 1999b). The probable explanation is that the past quarter century has not witnessed the same technological breakthroughs as occurred in the previous quarter century when air traffic control was deployed and second generation jets displaced turboprop aircraft. One segment of the industry that has witnessed substantial improvement in recent times is commuter ("Part 135") operations. This segment expanded rapidly after deregulation as the mainline airlines moved to hub-and-spoke operating strategies. The expansion produced a technology-driven safety improvement, as increased demand led to the deployment of larger and safer aircraft. Piston-engine aircraft with less than twenty seats were replaced with larger turboprop aircraft, which were subsequently superseded by 50-seat or larger "regional jets." In 1997, most of this segment of the industry was brought under the same safety regulations as the mainline jet carriers.

Some critics have identified safety problems associated with deregulation. In the mid-1980s, there was concern that competitive pressures had led some airlines to cut safety expenditures, with the finger being pointed at some long-established airlines that had to file for bankruptcy. Academic research, based primarily on pre-deregulation data, indicated that there was a positive relationship between financial performance and safety performance for medium and smaller sized carriers (Rose, 1990). The problem with this hypothesis is that, excluding 1985, the early 1980s was also the safest period (in terms of passenger fatalities) in the history of aviation. There was also concern that new entrant carriers might be less safe than those already in the industry. Research concluded that the entrants of the early period of deregulation had similar safety records to established firms (Kanafani and Keeler, 1989). However, the same was not true for the entrants in the early to mid-1990s. The closure of the rapidly-expanding ValuJet in 1996, following a crash near Miami, garnered much publicity. This was due to revelations of significant operating and maintenance problems.

Viscusi's $(1987,1989)$ analysis of workplace safety looked at all three modes over the period 1972 to 1985. He used Bureau of Labor Statistics (BLS) data on workplace injuries and illnesses. He ran regressions on the logarithm or log-odds of three different measures of 
workplace safety: the rate of injuries and illnesses per 100 full-time equivalent (FTE) employees, the rate of injuries and illnesses requiring time way from work or assignment to another job, and the rate of total lost workdays (number of cases multiplied by the length of time away from regular duties). His explanatory variables include the lagged dependent variable, the change in the number of people employed in the industry and deregulation dummy variables. The deregulation variable was not statistically significant in the regressions for any of the risk measures for the airline, trucking or (in the 1987 publication only) railroad industries. The coefficients tended to be negative. Viscusi repeated the analysis, using output rather than a count of workers as the denominator of risk. Again he found no significant relationship with deregulation. Of course, the statistical power of his analysis was hampered by the limited number of observations.

\section{Injury Data}

The collection of the data used by both Viscusi and this analysis was mandated by the Occupational Safety and Health Act of 1970. The first full-year report was 1972 (U.S. Department of Labor, various years). Data for railroads were not reported until the following year, which will be the first year for this analysis. The most recent data available for this analysis were for 2001. The data are collected by surveys sent to about 175,000 employers under a joint federal and state program. Employers have to report various statistics on the number of occupational injuries and illnesses, and the number of employee hours worked. One of the few exceptions to this process is the railroad industry, where the data are collected by the Federal Railroad Administration, which had already been collecting data of this nature for sixty years. The BLS uses these reports to produce industry-level statistics based on Standard Industrial Classification (SIC) codes at the three- or four-digit level. Data were extracted for three transportation modes and a control group occupation:

Railroads (SIC code 40), which covers "mainline” railroads and excludes mass transit systems other than commuter railroads. The data cover not only the large "class I" railroads but also the smaller “class II” and “class III” railroads.

Trucking and courier services (except air) (SIC code 421), formerly known as "trucking local and long distance." This SIC code only includes the commercial trucking sector. It excludes private trucking. Hours and injuries to trucking workers in these later companies are classified by the SIC code of the firm's principal business activity, such as petroleum refining or grocery store operation. Because the intent of the 1970 Act was to deal with the safety of employees, no data are collected on self-employed persons. This does not mean that all "owner-operators" are excluded. Owner-operators who work under long-term lease arrangements with larger trucking firms should, in theory, have their hours of work and injuries reported by the larger firm. This is because the BLS definition of an "employee" includes all those who work under a firm's direction regardless of the remuneration structure. In addition the BLS claims that it makes efforts to survey small firms, which will include those "owner-operators" who employ additional drivers or mechanics.

Air transportation, scheduled and air courier (SIC code 451), formerly known as "certified air carriers." This includes both the mainline and commuter airline industries offering scheduled service under Parts 121 and 135 of the Federal Air Regulations. The haphazard growth 
of the courier business over the past thirty years, with some major firms developing from an aviation base and some from a trucking base, led to a major continuity break in 1996. In the words of the BLS publication for that year, "air courier operations previously classified in Industry Groups 421, 422, 423, 452, 473, and 478 were reclassified to Industry Group 451.” The effect was to transfer 300,000 employees who had been previously classified as working in trucking to scheduled air service. This reduced the number of trucking employees by about a sixth, and boosted aviation employment by about $50 \%$.

The control group occupation was Manufacturing (SIC division D). This was chosen for a several reasons. First, manufacturing might be regarded as providing a substitute occupation for the skills of transportation workers. Second, there are similar occupational hazards such as the use of heavy machinery. Third, manufacturing is one of the few industry classifications for which the government collects data on output. Output is used as a denominator of risk for the second part of this analysis.

Other than the reclassification of courier service, data have been collected in a consistent manner over time and reported in a broadly similar format, although the degree of detail expanded significantly after 1992. That said, only one appropriate data series has been reported consistently since the beginning. That is "lost workday injuries per 100 full-time-equivalent (FTE) employees.” A lost workday injury means that the employee had to stay at home or, if they remained at work, had restricted activity or had to be transferred to another task. The data used is the number of cases, not the sum total of lost workdays. An FTE employee is defined by dividing the number of hours worked by 2,000 (50 weeks at 40 hours a week). There may be some ambiguity in defining "restricted activity," so some analysts prefer the measure of "injuries with day(s) away from work." These are injuries that require the employee to be absent from the workplace. Unfortunately, these data are only available from 1976, which would limit even further the evidence on pre-deregulation trends. Graphical analysis of the two measures for each industry since 1976 indicates that they track each other quite closely.

The analysis is confined to industrial injuries and, unlike Viscusi, excludes illnesses. The primary reason is that, unlike physical injuries, illnesses may only become apparent years after exposure to the unhealthy condition, and possibly after the employee has moved to another occupation. This paper only deals with non-fatal injuries. Comprehensive fatality data only became available in 1992, and suffer from the problem that there is considerable year to year variation. For example, railroad and aviation fatalities have been as low as twenty in some years, and susceptible to variation due to multiple-fatality incidents.

\section{Injury Rates per Employee}

Figure 1 shows a graph of the rates of lost workday injuries per 100 FTE employees for the three transportation modes and manufacturing. Probably the most notable feature is the trend for railroads. Railroad injury rates were the lowest of all of the occupations in 1973, but rapidly deteriorated throughout the 1970s. Then in 1980 the rate started to fall, and by the mid-1990s railroads had once again become the safest of the occupations. This is consistent with the data on collisions and derailments. One does not need to deploy econometric analysis to conclude that deregulation of the railroads coincided with improved workplace safety. The effects in the 
trucking and aviation industries are less clear. Excepting the discontinuity in 1996, visual inspection suggests that injury rates have been fairly constant, with some cyclical variations. Injury rates in manufacturing started out at about half those in trucking and aviation, and have stayed remarkably constant over the decades.

All of the data series seem to exhibit similar cyclical trends. Injury rates appear to have increased in the late 1970s, declined in the early 1980s, increased again at the end of the 1980s, and fell again in the early 1990s. This phenomenon has been observed by labor economists. These trends coincide with expansion and contraction of economic activity, and in the case of some of the industries an increase and decrease in the numbers employed. The standard argument is that during times of employment growth, less skilled and more accident-prone workers are employed, and during a contraction, these are the first employees to be let go. The exception has been the decline in injury rates during the economic expansion of the mid to late 1990s. My conversations with BLS staff indicate that the BLS is unsure of the explanation for this change from previous experience.

The formal analysis in this paper uses the ratio of the injury rates in each of the transportation modes to that of manufacturing. The use of this ratio removes the effects of the business cycle, and potentially corrects for other changes in society that have affected the safety of all occupations. Figure 2 shows this relative injury risk ratio for each mode. Econometric techniques are used to analyze the slopes of the data in Figure 2 in order to tell whether trends after deregulation have differed from those in the 1970s. The regressions use first-difference techniques so as to avoid the usual autocorrelation problems that arise with time-series data. Consequently, the first observation will be for the year 1974, and be the value of the variable in that year less its value in 1973, and so on. Separate regressions will be conducted for each of the three transportation modes.

The following regression is estimated for each mode:

$$
\ln \left(\text { Ratio }_{\text {it }} / \text { Ratio }_{\text {it- } 1}\right)=\beta_{1} \cdot 1+\beta_{2} \cdot 1 \cdot \text { Dereg }_{t}+\beta_{3} \cdot \text { Courier }_{t}+\varepsilon
$$

In the dependent variable, Ratio $_{i t}$ is the ratio of injuries per employee in transportation mode $\mathrm{i}$ in period $t$ relative to the rate for manufacturing. The subscript $t-1$ indicates the previous year. The dependent variable, the ratio of risks, is expressed as a logarithm to ensure that the estimated values are positive. It is illogical for an injury rate to take negative values. Two explanatory time trend variables are used to represent the slopes of the relationships in Figure 2. The first is an underlying time trend for the entire period. Because the equation is estimated in first differences, this variable will take the value one in each time period. An additional time trend starts in the first full year of deregulation. Aviation deregulation took effect on October 28, 1978, so for this mode Dereg $_{t}$ is a dummy variable taking the value one in 1979 and later years. Trucking deregulation took effect on July 1, 1980 and the Staggers Act was signed on October 14, 1980. For these two modes, Dereg ${ }_{t}$ takes the value one in 1981 and later years. The interpretation of the regression is that the trend (slope) of the relative injury risk prior to deregulation is given by $\beta_{1}$, whereas after deregulation it is given by $\left(\beta_{1}+\beta_{2}\right)$. Finally, a dummy variable is used in the trucking and aviation regressions to represent the discontinuity in the data due to the redefinition of courier services in 1996. Because the estimated equations are calculated as first-differences, this effect 


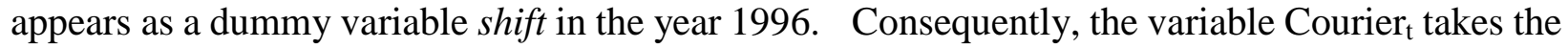
value one in 1996 and zero otherwise.

The results are shown in Table 3. The estimated coefficients confirm the visual impressions from Figures 1 and 2 . For the railroads $\beta_{1}$ is statistically significant and positive, and $\beta_{2}$ is negative and statistically significant. Moreover, the absolute value of $\beta_{2}$ is greater than $\beta_{1}$. This means that there was a strong upward (i.e., less safe) trend in relative workplace safety prior to deregulation. However, the magnitude of the (negative) $\beta_{2}$ is so large that it more than canceled out the deteriorating safety trend, and led to safety improvements after deregulation. This produces the inverted V shape of the railroad safety risk shown in Figures 1 and 2.

In contrast, for trucking and aviation, neither $\beta_{1}$ nor $\beta_{2}$ are statistically significant. The magnitudes of the coefficients are much smaller than those for the railroads, and because $\beta_{1}$ and $\beta_{2}$ have opposite signs, they tend to cancel each other out in the post-deregulation period. In summary, there is no significant underlying time trend, and deregulation does not seem to have altered the situation. Only the redefinition of air couriers has any significant effect.

\section{Injury Rates per Unit of Output}

The preceding analysis is most appropriate for examining workplace safety from the point of view of employees. It answers the question about the relative risk that employees face in any given year by working in transportation compared with a peer occupation. While society also shares this concern, the metric it uses may be somewhat different. Society may be more interested in the rate of injuries per unit of output. Even if the rate per employee remains constant, improvements in productivity will mean that fewer employees will be injured per unit of output, and hence the industry would in some sense be "safer." This relationship is somewhat controversial. Productivity increases, such as the removal of firemen from diesel railroad locomotives and cabooses from the rear of trains, were argued at the time to lead to a greater safety risk. Yet at the same time, these changes removed staff from very vulnerable positions and probably contributed to overall improved worker safety.

For this analysis, the measure of railroad output is ton-miles of freight moved by all classes of railroads (Eno Transportation Foundation, various years). Because BLS data for trucking injuries is only for the "commercial" segment of the industry, the most appropriate measure of output is a series called domestic inter-city ton-miles for "Interstate Commerce Commission trucks” (Eno Transportation Foundation, various years). For scheduled aviation, the output measure is revenue passenger enplanements on scheduled flights by U.S. flag carriers (Federal Aviation Administration, various years). This type of output measure is commonly used in aviation safety analysis, rather than passenger miles, because most of the crash risk occurs during the takeoff and landing stages of flight. In addition, the amount of ground handling whereby gate agents, ramp employees and maintenance personnel might be injured will be largely invariant with the length of the flight. Output data for manufacturing is obtained in a monthly survey (Board of Governors of the Federal Reserve System, monthly). This is a measure of physical output, and is shown as an index using a base of 1997 equals 100. For the purposes of this analysis, the base of the index was changed to 1973 equals one. 
Figure 3 shows trends in the ratio of total industry employment to output for the three transportation modes and manufacturing. For the sake of easy comparison, the data have been normalized so that the rate in 1973 for each industry is set equal to 100 . Railroad productivity has improved continuously and dramatically since the mid-1970s. The ratio of employees to output is now only $27 \%$ of the level at the time of deregulation. The railroad productivity improvements have been greater than the remarkable 54\% improvement in manufacturing productivity over the same period. In contrast, the trends in trucking and aviation productivity are less clear. There was improved productivity in the 1970s and again in the early 1990s, but constant and perhaps deteriorating trends in other time period. The reclassification of air courier employees in 1996 produces a significant discontinuity in both data series. The implication is that the improved railroad productivity post-deregulation should exacerbate the earlier finding that deregulation was associated with improvements in employee safety, while the effects in the trucking and aviation industries are not readily apparent.

Data are available to directly calculate the rate of total lost workday injuries per unit of output for all years for railroads and manufacturing, and from 1992 onward for trucking and aviation. For earlier years in the later modes, the total number of injuries can be inferred by multiplying the rate of injuries per 100 FTE employees by an estimate of FTE employees derived from employment data. Details of these calculations are in the data appendix. Total injuries are then divided by output to obtain an injury rate. A summary of the denominator of injury rates for the various industries are shown in Table 4. The choice of the orders of magnitude for the various units of output was made so that the injury rates for the various industries were of comparable magnitudes, typically between one and ten per unit of output.

Figure 4 shows the trends in injuries per unit of output for each of the three transportation modes and manufacturing. For ease of comparison, the data are shown as an index with 1973 set equal to 100. The adverse trend in employee injury rates on the railroads relative to manufacturing prior to deregulation, followed by a distinct subsequent improvement is clearly apparent. The effect is a lot more dramatic than the decline in injuries per employee shown in Figure 1. The relative injury rate in both trucking and aviation has no discernable trend, but considerable year-to-year variation. The effect of the reclassification of air courier employees in 1996 is very obvious. The stagnation of injury rates in aviation and trucking compares unfavorably with the downward trend in injury rates in manufacturing which started in the late 1970s.

Figure 5 shows an index for each transportation mode of the ratio of the injury rates to that of manufacturing. For comparison purposes, the value of each index series in 1973 is set equal to 100. The slow deterioration in injury rates in aviation and trucking relative to manufacturing is readily apparent. Between the late 1970s and the redefinition of air couriers in 1996, safety per unit of output declined by about 50\% compared with manufacturing. For the railroads, the post-deregulation improvement in safety in Figure 4 is somewhat muted in Figure 5 because manufacturing has also seen improvements in productivity.

A second group of regressions was conducted on the base data underlying the indices in Figure 5. As before, the dependent variable is transformed into logarithms to avoid predicting a 
negative ratio of relative risk. A first difference specification is used to reduce econometric problems. The right-hand-side variables are the same as the first group of regressions:

$\ln \left(\right.$ Ratio $_{\text {it }} /$ Ratio $\left._{\text {it- } 1}\right)=\beta_{1} \cdot 1+\beta_{2} \cdot 1 \cdot$ Dereg $_{t}+\beta_{3} \cdot$ Courier $_{t}+\varepsilon$

where Ratio it is the ratio of injuries per unit of output in transportation mode $\mathrm{i}$ in period $\mathrm{t}$ relative to the rate for manufacturing. The other variables are as defined earlier.

The regression results are shown in Table 5. For the railroads $\beta_{1}$ is almost statistically significant at the $5 \%$ level and positive, and $\beta_{2}$ is negative, highly statistically significant, and $75 \%$ larger than $\beta_{1}$. This means that there was an upward (i.e., less safe) trend in relative workplace safety prior to deregulation, that was more than compensated for in the years after deregulation. As in the earlier analysis with respect to injuries per employee, there is an inverted $\mathrm{V}$ shape relationship. For trucking and aviation, both $\beta_{1}$ and $\beta_{2}$ are positive, but small, and neither is statistically significant. Even when the effects are combined together, one cannot reject the null hypothesis of a zero slope at the $10 \%$ level. Contrary to the visual suggestion of Figure 5, one cannot definitively conclude that relative workplace safety has declined in these industries. Only the redefinition of air couriers has any significant effect in the regressions.

\section{Conclusions}

Only in railroads does there appear to be any linkage between deregulation and workplace safety. There is evidence that safety started to deteriorate in the mid-1960s. The cause was the financial crisis which led to bankruptcies in the eastern United States, and a more general rundown in the infrastructure. The federal government addressed this problem with the introduction of comprehensive safety regulation in 1970. Previously, the industry was largely self-regulated. Specific rules were written and a federal and state inspectorate was hired over the course of the 1970s. Despite this, workplace safety continued to deteriorate throughout the 1970s. Deregulation in 1980 led to a financial renaissance of the industry. Capital expenditures increased significantly. It is obvious from a graphical analysis, and confirmed by regressions, that the previous upward trend in workplace injuries was reversed. By the early 1990s the injury rate was lower than it was in 1973. This improving trend was magnified by increased productivity. The rate of employee injuries per ton mile is now only a quarter of what it was in 1979.

In contrast there has been no statistically-significant trend in the rate of workplace injuries in trucking and scheduled aviation, and no effects of deregulation can be detected. This finding is consistent with aviation crash data which shows a stagnation in crash rates since the mid-1970s, following rapid technology-driven improvements in the 1960s. It would appear that technology and employee safety is also stagnant in other aspects of aviation, such as ramp operations, maintenance and customer service.

In trucking, there is evidence that the rate of fatal crashes on the public highway involving heavy trucks has declined by 50\% over the past twenty-five years. However, this is not evident in workplace injury data. There are several explanations for this inconsistency. Much of the reduction in highway crash rates has come from improved occupant protection of passenger 
vehicles that are in collision with heavy trucks. Occupants of these vehicles, rather than truck drivers, are disproportionately victimized by crashes. Moreover, injuries in traffic crashes only represent a small minority of injuries sustained by trucking employees. It would appear that other injury-producing aspects of the trucking profession such as loading and unloading, and climbing in and out of cabs, has not changed much in the past thirty years.

\section{References}

Board of Governors of the Federal Reserve System (monthly) Industrial Production and Capacity Utilization. Washington D.C.: Board of Governors of the Federal Reserve System.

Bulow, Jeremy, and John Shoven (1978) “The bankruptcy decision,” Bell Journal of Economics, vol. 9(2), pp. 437-456.

Corsi, Thomas M, and Philip Fanara (1989) "Effects of new entrants on motor carrier safety." In Leon N. Moses and Ian Savage (eds.) Transportation Safety in an Age of Deregulation, New York: Oxford University Press.

Eno Transportation Foundation (various years) Transportation in America. Washington, D.C.: Eno Transportation Foundation.

Federal Aviation Administration (various years) Air Carrier Traffic Statistics, Washington, D.C.: U.S. Government Printing Office. (Prior to 1983 published by the Civil Aeronautics Board.)

Kanafani, Adib, and Theodore E. Keeler (1989) "New entrants and safety.” In Leon N. Moses and Ian Savage (eds.) Transportation Safety in an Age of Deregulation, New York: Oxford University Press.

Klein, Benjamin, and Keith E. Leffler (1981) "The role of market forces in assuring contractual performance,” Journal of Political Economy, vol. 89(4), pp. 615-641.

Moses, Leon N., and Ian Savage (1989) Transportation Safety in an Age of Deregulation, New York: Oxford University Press.

Moses, Leon N. and Ian Savage (1997) “A cost-benefit analysis of United States motor carrier safety programs,” Journal of Transport Economics and Policy, vol. 31(1), pp. 51-67.

Rose, Nancy L. (1990) "Profitability and product quality: economic determinants of airline safety performance,” Journal of Political Economy, vol. 98(5), pp. 944-964.

Savage, Ian (1998) The Economics of Railroad Safety, Boston, Mass.: Kluwer Academic Publishers. 
Savage, Ian (1999a) “The economics of commercial transportation safety.” In Gómez-Ibáñez, José A., William B. Tye and Clifford Winston (eds.) Essays in Transportation Economics and Policy: A Handbook in Honor of John R. Meyer, Washington D.C.: Brookings Institution.

Savage, Ian (1999b) "Aviation deregulation and safety in the United States: evidence after twenty years.” In Gaudry, Marc and Robert Mayes (eds.) Taking Stock of Air Liberalization, Boston: Kluwer Academic Publishers.

Shapiro, Carl (1982) "Consumer information, product quality, and seller reputation," Bell Journal of Economics, vol. 13(1), pp. 20-35.

United States Department of Labor, Bureau of Labor Statistics (various years) Occupational Injuries and Illnesses in the United States by Industry, Washington, D.C.: U.S. Government Printing Office. (Known as Occupational Injuries and Illnesses - Counts, Rates and Characteristics from 1992.)

Viscusi, W. Kip (1987) "The effect of transportation deregulation on worker safety” Proceedings of the Transportation Deregulation and Safety Conference, Evanston, Ill.: Northwestern University Transportation Center.

Viscusi, W. Kip (1989) “The effect of transportation deregulation on worker safety.” In Leon N. Moses and Ian Savage Transportation Safety in an Age of Deregulation, New York: Oxford University Press.

\section{Data Appendix}

This appendix describes the data preparation that was necessary to deal with years for which certain data items were either missing or reported inconsistently. For 1977-79, the rate of lost workday injuries per 100 FTE employees was not shown at a sufficient level of disaggregation for scheduled aviation. For these years, the reported rate for "Transportation by Air" (SIC code 45) was adjusted using the ratio of the injury rate in SIC 451 to SIC 45 observed in 1976 and 1980.

Injury rates per unit of output are calculated by dividing total lost workday injuries by the measures of output that are described in the text. While information of total injuries is reported each year for railroads and manufacturing, they are only given at a sufficient level of disaggregation for trucking and aviation since 1992. For the earlier years in trucking and aviation, it is necessary to estimate the total number of injuries by multiplying the known rate of injuries per 100 FTE employees by an estimate of the FTE employees in those years. Because FTE data are never shown explicitly in the published data, another BLS database, the "Covered Employment and Wages (CEW) Program," is used as the basis for employment data.

Because the survey methods are different, CEW employment numbers may not accord with the FTE data collected as part of the injury surveys. However, for the years between 1992, when reporting was expanded, and 1996, when courier services were reclassified, it is possible to compare the CEW employment data with an implied value for FTE employees. The latter are calculated by dividing total injuries by the injury rate per 100 FTE employees. For trucking the 
FTE employee number appears to be about 0.983 times the CEW employment number. The equivalent number for aviation is lower at 0.874. An estimation of FTE employees for earlier years can be made by multiplying the CEW employment figures by these factors.

CEW employment data were reported for SIC 421 and 451 in 1976, 1983-84, 1986-87, and from 1989. For the trucking industry, the missing data were estimated using the ratio to the employment in trucking (SIC 421) to total employment in Trucking and Warehousing (SIC 42) less the reported number of employees in Warehousing (SIC 422) from neighboring years when the full data are known. The numbers are always very close. Missing data for 1973-75 and 1977-82 are calculated by using the average ratio of (SIC 42 - SIC 422)/SIC 421 for 1976 and 1983. The 1985 data were estimated by using the average ratio for 1984 and 1986, and the 1988 data were estimated using the average ratio in 1987 and 1989.

Similar calculations were made for aviation. For 1973-75 and 1977-82 employment was estimated by using the average ratio of employment in scheduled air transportation (SIC 451) to total aviation (SIC 45) in 1976 and 1983. The 1985 and 1988 data were calculated by using the ratio of employment in SIC 451 to total employment in SIC 45 less employment in "Airports, Flying Fields and Airport Terminal Services" (SIC 458). As with trucking, the 1985 data were estimated by using the average ratio for 1984 and 1986, and the 1988 data were estimated using the average ratio in 1987 and 1989.

Because total injury data is given every year for the railroads, it is not necessary to use employment numbers to estimate these data. However, employment data is used as the numerator of the productivity rates shown in Figure 3. Railroad employment data from the CEW survey is missing after 1995. Fortunately alternative data are available from the Department of Labor's "Current Employment Survey." These two data series have always been almost identical. 
Table 1: Causes of Lost Workday Injuries and Illnesses 2000

\begin{tabular}{|l|c|c|c|c|}
\hline & Railroads & Trucking & Aviation & $\begin{array}{c}\text { All Private } \\
\text { Industry }\end{array}$ \\
\hline Overexertion & $18 \%$ & $29 \%$ & $40 \%$ & $27 \%$ \\
\hline Contact with object & $18 \%$ & $25 \%$ & $22 \%$ & $27 \%$ \\
\hline Slips \& Falls & $22 \%$ & $21 \%$ & $16 \%$ & $21 \%$ \\
\hline Transportation Accidents & $12 \%$ & $12 \%$ & $4 \%$ & $4 \%$ \\
\hline Exposure to harmful substances & $4 \%$ & $2 \%$ & $3 \%$ & $4 \%$ \\
\hline Repetitive Motion & $1 \%$ & $1 \%$ & $2 \%$ & $4 \%$ \\
\hline Assaults & $1 \%$ & $0 \%$ & $1 \%$ & $1 \%$ \\
\hline Other & $24 \%$ & $10 \%$ & $12 \%$ & $11 \%$ \\
\hline
\end{tabular}

Table 2: Nature of Lost Workday Injuries and Illnesses 2000

\begin{tabular}{|l|c|c|c|c|}
\hline & Railroads & Trucking & Aviation & $\begin{array}{c}\text { All Private } \\
\text { Industry }\end{array}$ \\
\hline Sprains and Strains & $57 \%$ & $50 \%$ & $53 \%$ & $44 \%$ \\
\hline Bruises & $17 \%$ & $10 \%$ & $12 \%$ & $9 \%$ \\
\hline Cuts, Punctures & $7 \%$ & $6 \%$ & $3 \%$ & $9 \%$ \\
\hline Fractures & $8 \%$ & $8 \%$ & $3 \%$ & $7 \%$ \\
\hline Other Pain & $0 \%$ & $3 \%$ & $9 \%$ & $4 \%$ \\
\hline Multiple Trauma & $0 \%$ & $4 \%$ & $2 \%$ & $4 \%$ \\
\hline Back Pain & $0 \%$ & $3 \%$ & $5 \%$ & $3 \%$ \\
\hline Carpal Tunnel Syndrome & $0 \%$ & $1 \%$ & $1 \%$ & $2 \%$ \\
\hline Heat Burns & $0 \%$ & $1 \%$ & $0 \%$ & $1 \%$ \\
\hline Tendinitis & $0 \%$ & $1 \%$ & $0 \%$ & $1 \%$ \\
\hline Amputations & $1 \%$ & $0 \%$ & $0 \%$ & $1 \%$ \\
\hline Chemical Burns & $0 \%$ & $0 \%$ & $0 \%$ & $1 \%$ \\
\hline Other & $10 \%$ & $14 \%$ & $12 \%$ & $16 \%$ \\
\hline
\end{tabular}


Table 3: First-Difference Regression Results on Logarithm of Lost Workday Injury Cases per 100 FTE Employees in Transportation Relative to Manufacturing

\begin{tabular}{|l|c|c|c|}
\hline Coefficient (t statistic in parentheses) & Railroads & Trucking & Aviation \\
\hline Time Trend & 0.094 & -0.009 & 0.025 \\
& $(2.47)$ & $(0.24)$ & $(0.76)$ \\
\hline Deregulation (1981 on for trucking/rail, & -0.124 & 0.013 & -0.022 \\
1979 on for aviation) & $(2.81)$ & $(0.32)$ & $(0.62)$ \\
\hline Courier Redefinition (1996) & - & -0.284 & 0.474 \\
& & $(2.93)$ & $(6.44)$ \\
\hline $\mathrm{R}^{2}$ & 0.233 & 0.261 & 0.640 \\
\hline Observations & 28 & 28 & 28 \\
\hline
\end{tabular}

Table 4: Measures of Industry Output used to Calculate Injury Rates

\begin{tabular}{|l|c|}
\hline \multicolumn{1}{|c|}{ Industry } & Output Measure \\
\hline Railroads & 100 Billion Ton-Miles \\
\hline Trucking & 10 Billion Ton-Miles \\
\hline Aviation & 10,000 Revenue Passengers Enplaned \\
\hline Manufacturing & Index of Manufacturing Production with $1973=1$ \\
\hline
\end{tabular}

Table 5: First-Difference Regression Results on Logarithm of Rate of Lost Workday Injury Cases per Unit of Output in Transportation Relative to Manufacturing

\begin{tabular}{|l|c|c|c|}
\hline Coefficient (t statistic in parentheses) & Railroads & Trucking & Aviation \\
\hline Time Trend & $\begin{array}{c}0.080 \\
(1.92)\end{array}$ & $\begin{array}{c}0.004 \\
(0.11)\end{array}$ & $\begin{array}{c}0.006 \\
(0.18)\end{array}$ \\
\hline Deregulation (1981 on for trucking/rail, & -0.141 & 0.027 & 0.018 \\
1979 on for aviation) & $(2.93)$ & $(0.50)$ & $(0.48)$ \\
\hline Courier Redefinition (1996) & - & -0.423 & 0.858 \\
& & $(4.02)$ & $(11.01)$ \\
\hline $\mathrm{R}^{2}$ & 0.280 & 0.395 & 0.845 \\
\hline Observations & 28 & 28 & 28 \\
\hline
\end{tabular}




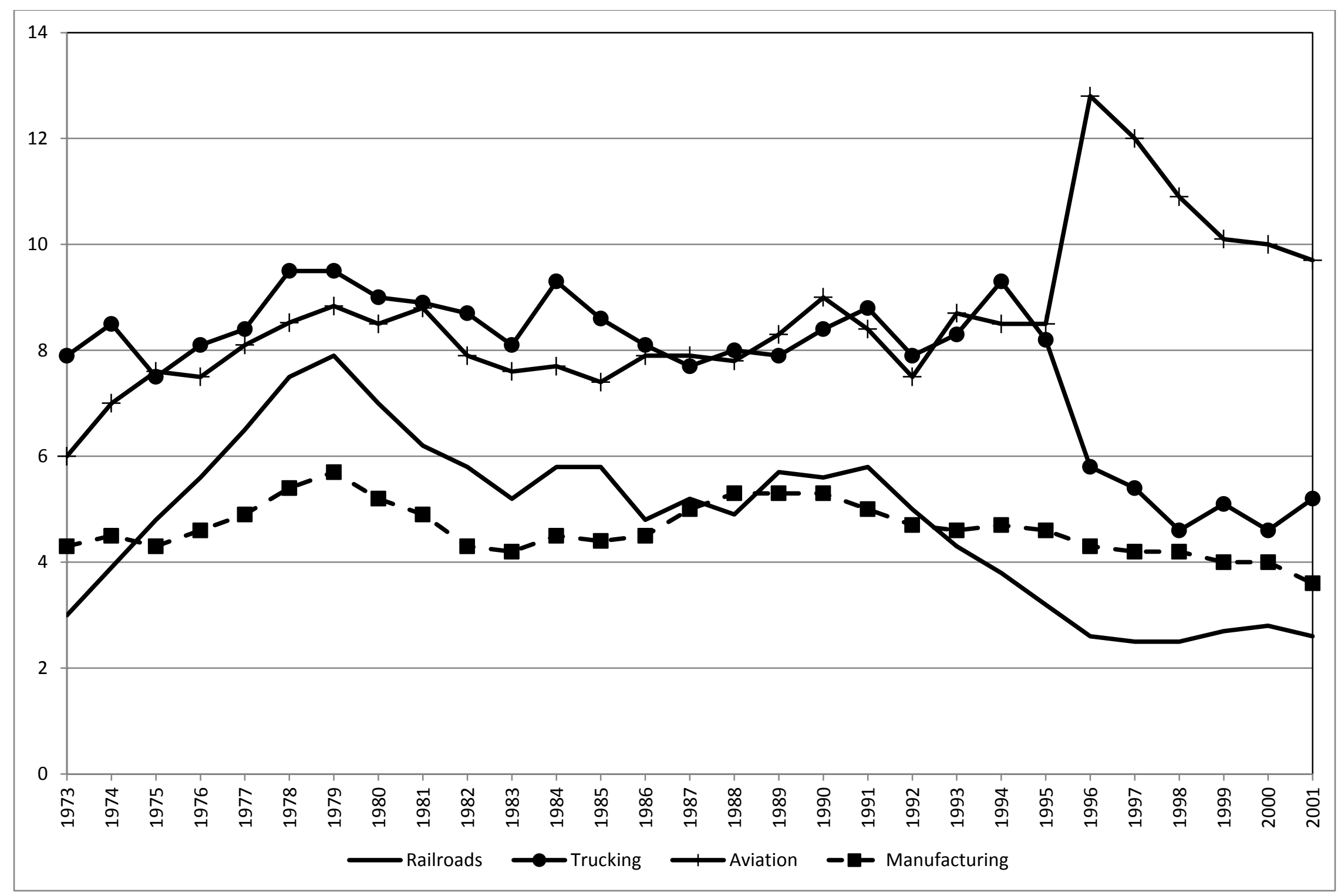

Figure 1: Lost Workday Injuries per 100 Full Time Equivalent Employees (FTE). 


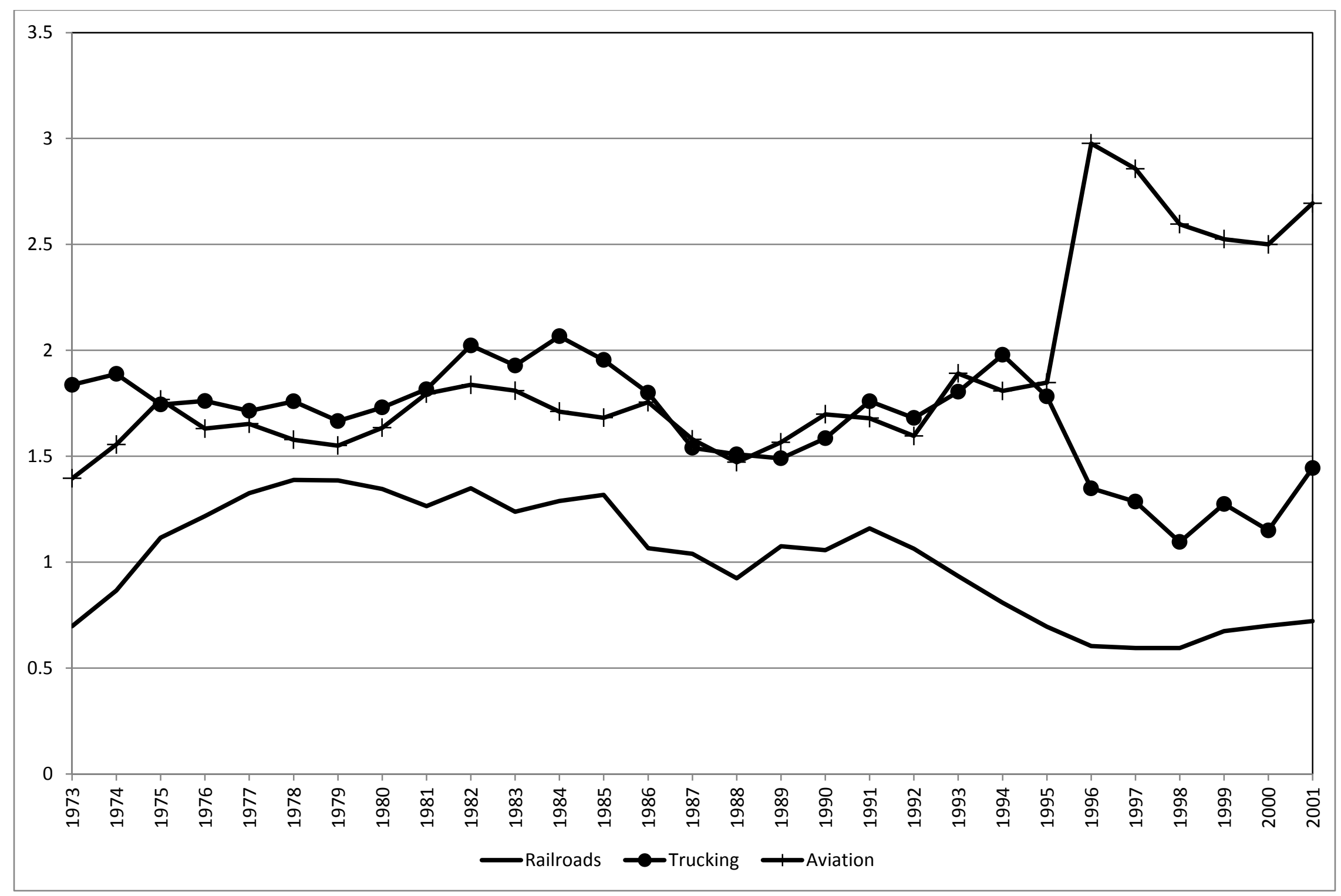

Figure 2: Lost Workday Injury Cases per 100 Full Time Equivalent Employees (FTE) Relative to Manufacturing. 


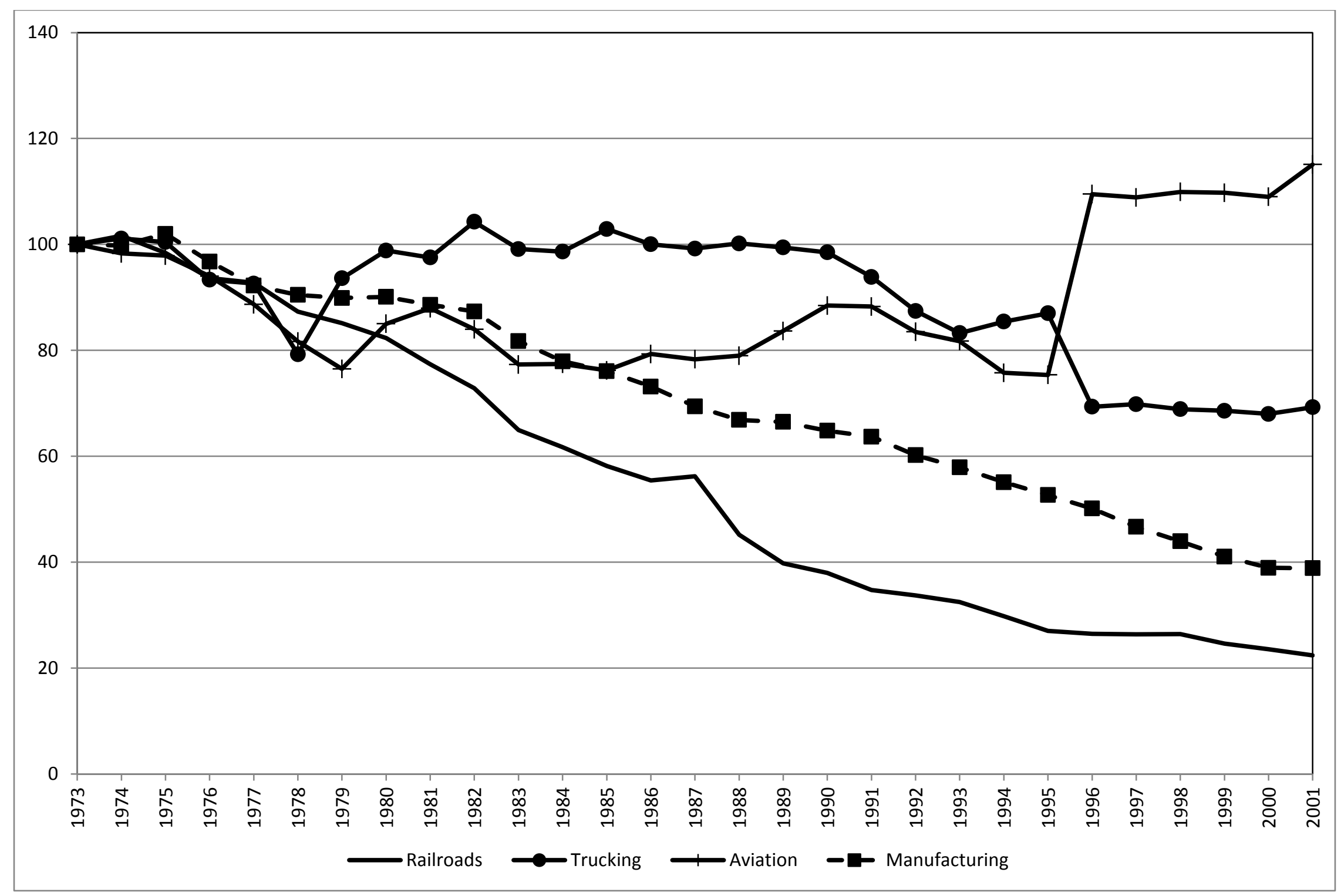

Figure 3: Index of Employment to Output with 1973=100. 


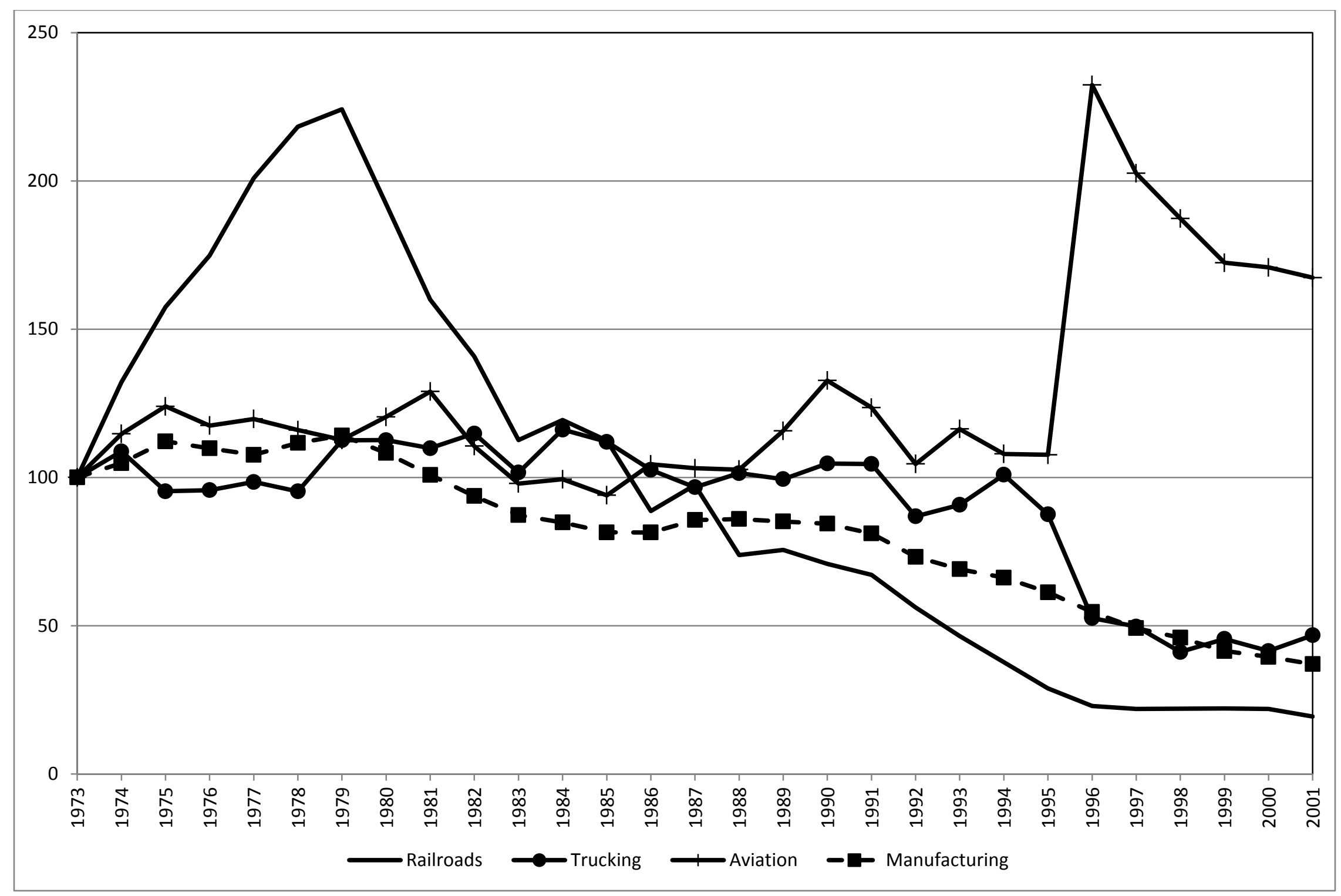

Figure 4: Index of Lost Workdays per Unit of Output with 1973=100. 


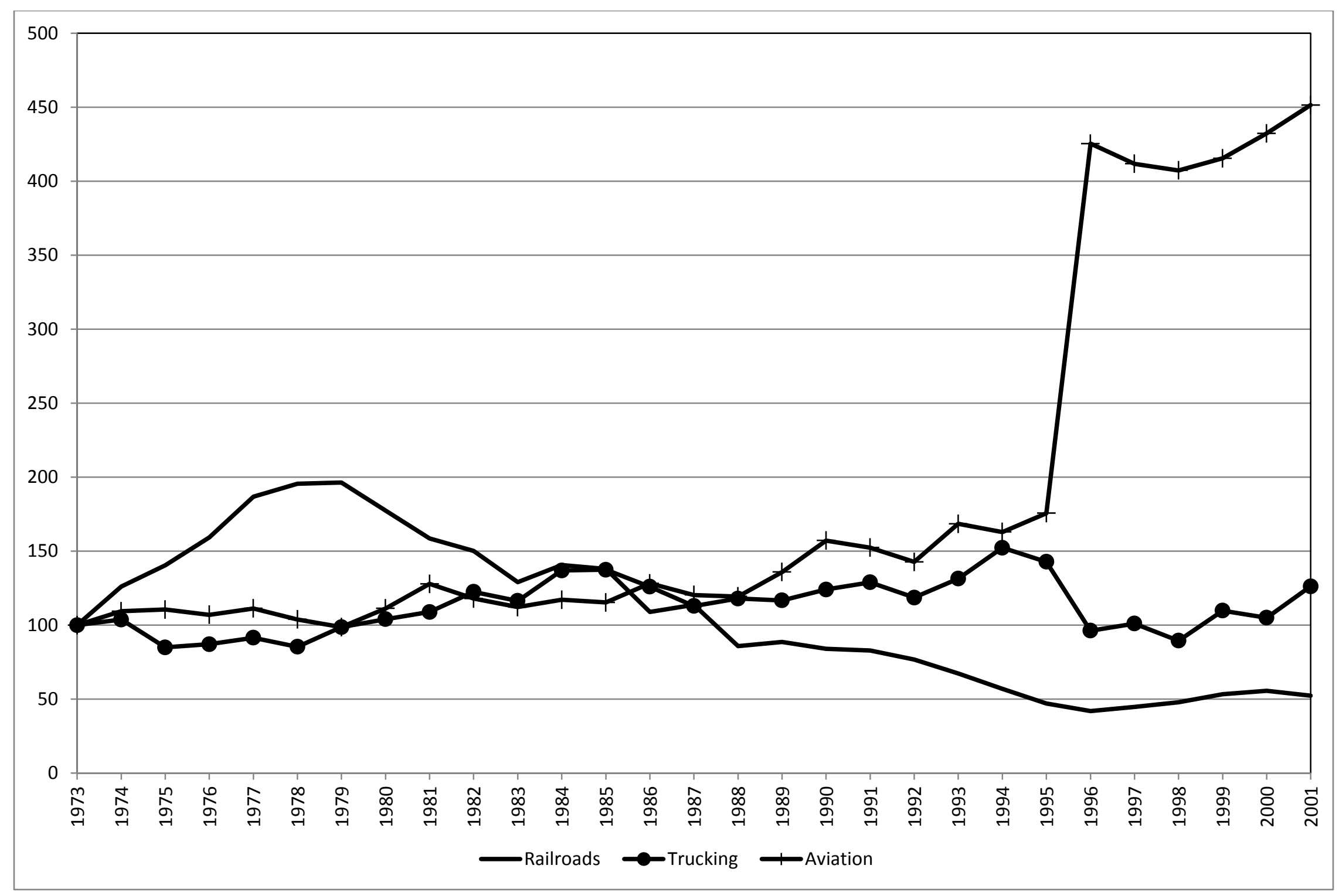

Figure 5: Index of Lost Workday Injuries per Unit of Output Relative to manufacturing with 1973=100. 